and schools, which are described at the end of the chapter. The final part of the chapter is dedicated to children's publisher Aldona Liobyte (1915-1985). In a manner similar to the previous chapters, which describe the development of picture books until the 1950s, the next two chapters focus on the following decades.

“The Dynamic 1960s: New Directions in Children's Books' Illustrations" presents the 1960 s as the age of modernisation and change. Illustrators of that time started using different means of expression, such as photomontage and colour paper-cuts. Illustrations were the perfect addition to a text and the change in art form and topics through the decades could easily be seen. Even though there was a never-ending battle against the strict censorship imposed by the regime, the old themes remained the same, neatly wrapped into a new, modern design. Besides being influenced by Western countries which brought many new forms of art into Soviet picture books (e.g. Pop Art), the artists decided to rediscover the past through "Primitive Modern" art. The chapter finishes with some thoughts on the impact of illustrations on young readers and the artists themselves. The chapter "Children's Books' Illustration in an Era of Stagnation: 1970s and After" presents the 1970s and 1980s as a time of inactivity, in which people drew back into their private lives. Still, the era of stagnation inspired two important developments: the translations of children's books from Polish, Czech, Finnish and Swedish, and the foundation of Vyturys, a specialist publisher of children's books in 1985. This chapter also mentions two new illustrators that emerged from the era - Stasys Eidrigevičius and Kęstutis Kasparavičius. The final and shortest chapter of the book is "Postscript from the Past", which delivers a conclusion on the second part of the book. It deals with the effect of illustrations on people living in Soviet Lithuania at that time. In addition, it offers some engaging illustrations as examples of the importance of Soviet picture books and their art.

From the very first glance, the book is compelling. The front cover illustration and the back cover and endpaper illustrations are borrowed from different picture books mentioned in the book, which perfectly encapsulates the subject. Through such marvellous covers, the authors immediately manage to draw the readers' interest. The text is very clear, and the facts are presented in detail and supported by illustrations. Even though the book uses specialist terms on occasions, the coherent text and supporting illustrations ensure that it is generally easy to read. I would recommend this book to all types of readers - scholars, teachers, and students interested in this field. The authors can certainly be credited for merging seemingly disparate things, and bringing some of the tough, intriguing past into the present.

Katarina Kokanović

\title{
O pripovjednoj slikovnici
}

Smiljana Narančić Kovač. 2015. Jedna priča - dva pripovjedača: slikovnica kao pripovijed. Zagreb: ArTresor naklada. 447 str. ISBN 978-953-8012-04-4

DOI: 10.21066/carcl.libri.2017-06(01).0012

U svojoj knjizi posvećenoj pripovjednoj slikovnici Smiljana Narančić Kovač uvodi nas u detaljno razmatranje slikovnice kao zasebne umjetničke knjige te pokazuje kako je tu naizgled vrlo jednostavnu književnu vrstu ipak potrebno pomnije proučiti i analizirati. Smiljana Narančić Kovač predaje na Učiteljskome fakultetu Sveučilišta u Zagrebu gdje, 
između ostaloga, drži kolegij posvećen slikovnicama na kojem već godinama znanje o njima i ljubav prema njima prenosi na svoje studente. Autorica je već u okviru svojega doktorskoga rada počela podrobno analizirati slikovnice i način na koji donose priču, a knjiga Jedna priča - dva pripovjedača temelji se upravo na njemu. Sadržaj i temelj istraživanja čine suvremene engleske, američke i hrvatske slikovnice među kojima su, primjerice, Rosie's Walk Pat Hutchins, Lily Takes a Walk Satoshia Kitamure, Voices in the Park Anthonyja Brownea i Moj put Svjetlana Junakovića.

Teorijska istraživanja slikovnice kao književne vrste započela su u 20. stoljeću, no tek im se u 21. stoljeću počelo pridavati veći značaj. Kada govorimo o istraživanju slikovnica u Hrvatskoj, ono je do danas vrlo slabo razvijena grana znanosti o književnosti o kojoj postoji vrlo malo literature. Narančić Kovač svojim je iscrpnim istraživanjem pripovjedne slikovnice uvelike pridonijela razvoju njezine teorije, a samim time $\mathrm{i}$ popularizaciji te umjetničke vrste. Potrebno je naglasiti da je ova knjiga prva monografija na hrvatskome jeziku u potpunosti posvećena istraživanju slikovnice i prva koja ih razmatra s humanističkoga stajališta (raniji radovi bili su uglavnom pedagoški orijentirani). Budući da je predmet studije pripovjedna slikovnica, odnosno ona koja donosi neku vrstu priče, autorica se u prvome redu bavi teorijom pripovijedi (the theory of narrative), postavljajući slikovnicu u njezine okvire. Misao vodilja cijeloga istraživanja pitanje je načina na koji pripovjedna slikovnica posreduje priču. Svojim iscrpnim istraživanjem autorica propitkuje vrlo rašireno stajalište da u slikovnici postoje dvije razdvojene priče, jedna vizualna, druga verbalna, te umjesto toga pokazuje da postoji jedna priča, ali da ju pričaju dva pripovjedača.

Autorica je za svoju knjigu odabrala naslov Jedna priča - dva pripovjedača koji potiče čitateljevo zanimanje za teoriju pripovjedne slikovnice jer daje naslutiti da se radi o posebnoj vrsti pripovijedanja s kojom nije upoznat velik broj ljudi. Knjiga je podijeljena na osam poglavlja u kojima autorica čitatelje postepeno uvodi u svijet pripovjednih slikovnica te im pomoću teorijskih saznanja objašnjava i približava način na koji one funkcioniraju.

U prvome, uvodnome poglavlju Narančić Kovač iznosi ciljeve svojega istraživanja. Ističe dvostruki diskurs, vizualni i verbalni, kao jedno od temeljnih obilježja suvremene slikovnice te naglašava njihovo zajedničko djelovanje u donošenju priče. Također navodi odnos pripovjedača tih dvaju diskursa kao središte zanimanja svoje studije, a kao jednu od njezinih bitnih značajki spominje i analizu pripovjednih perspektiva u slikovnici.

Drugo se poglavlje bavi teorijskim polazištima za analizu slikovnice. Autorica se u toj analizi služi „Genetteovom tipologijom pripovjedača i pripovjednih perspektiva, jer je pregledna, jasna i jednostavno primjenljiva“" (27). U okviru njegove tipologije opisane su vrste pripovijedanja i pripovjedača.

Osnovna tema trećega poglavlja pregled je teorije suvremene slikovnice s naglaskom na načinu na koji ona posreduje značenja. Vrlo zanimljiv dio ovoga poglavlja odnosi se na čitanje slikovnice, pri čemu autorica navodi tri karakteristična aspekta. Prvi se odnosi na prebacivanje čitateljske pozornosti između verbalnoga i slikovnoga diskursa za vrijeme čitanja (autorica objašnjava da čitatelj ne može istodobno pratiti oba diskursa). Drugi je aspekt čitanja interaktivnost koja je u slikovnicama iznimno naglašena zbog njihove složene pripovjedne strukture. Autorica objašnjava pojam interaktivnosti činjenicom da čitatelj sam bira redoslijed kojim će čitati slike i tekst na svakoj stranici. Posljednji je, treći aspekt opetovano čitanje koje je vrlo važno za slikovnice zbog višeznačnosti koje 
nalazimo u njima. Ostatak poglavlja istražuje vrste pripovjedača i pripovjednih perspektiva, ali i čitatelja. Važno je spomenuti i problematiku teorije slikovnice iznesenu na kraju ovoga poglavlja kojom autorica naglašava postojanje dubokoga jaza između teorije pripovijedi i teorije slikovnice.

U četvrtome je poglavlju iznesen teorijski model slikovnice kao pripovijedi. Narančić Kovač se u ovome poglavlju pretežito bavi potkrepljivanjem iznesene teorije primjerima slikovnica te na njima objašnjava načine na koje različiti diskursi zajednički donose priču. Vrlo je detaljno objašnjen i položaj pripovjedača koji je „kao sudionik pripovjedne komunikacije konstanta utoliko što ima nezaobilaznu ulogu u pripovijedi: pripovijeda priču i pritom vrši izbor i organizira pripovjedne informacije“ (136). Time je potvrđena teza o jednoj priči i dvama pripovjedačima, prema kojoj se u slikovnici za svaki diskurs, jezični i slikovni, javlja zaseban pripovjedač.

Pitanje slikovnoga i verbalnoga diskursa još je temeljitije razrađeno u petome poglavlju u kojem autorica detaljno opisuje načine na koje oni djeluju te kako su međusobno povezani. Za svoje spoznaje navodi i konkretne primjere i time omogućuje čitateljima jasno shvaćanje činjenice da različiti diskursi zapravo djeluju u suradnji svojih pripovjedača. Narančić Kovač ističe da ,slikovni pripovjedač u svoj diskurs može uključiti jezične aspekte i tako se otvoriti prema jezičnome pripovjedaču, a jezični pripovjedač može uključiti izražene vizualne aspekte i tako načiniti iskorak prema slikovnome pripovjedaču“ (222).

$\mathrm{U}$ šestome se poglavlju autorica bavi analizom pojedinih slikovnica i na primjerima objašnjava različite moguće kombinacije pripovjedača jezičnoga i slikovnoga diskursa. Te kombinacije prikazuje vrlo detaljnom i jasnom tablicom, a potom ih analizira $\mathrm{i}$ potkrepljuje primjerima. Na kraju poglavlja nalazi se jedan od najzanimljivijih dijelova ovoga istraživanja, a to su rezultati analize pripovjednih slikovnica. Analiza pokazuje da je moguć vrlo velik broj kombinacija obilježja jezičnoga i verbalnoga pripovjedača, a osobito je zanimljivo to što su rezultati i moguće kombinacije potkrijepljeni primjerima konkretnih slikovnica kao što su Zoo Anthonyja Brownea ili Peepo! Janet i Allana Ahlberga. Na taj se način teorija slikovnice približava čitateljima koji u poznatim slikovnicama mogu uočiti i primijeniti teoriju kojom se Narančić Kovač bavi i koju iznosi u svojoj knjizi.

Sedmo se poglavlje bavi povezivanjem teorijskoga modela slikovnice s modelom pripovjedne komunikacije. Model pripovjedne komunikacije u slikovnici autorica je izgradila „modifikacijom Chatmanove sheme pripovjedne transmisije“ (377), a u ovome poglavlju detaljno ga je opisala. Također, u sedmome se poglavlju objašnjavaju i odnosi sudionika pripovjedne komunikacije - pripovjedača i čitatelja. Narančić Kovač ističe da je u slikovnici ,čitateljeva uloga dodatno aktivna zbog prebacivanja s pripovjedanika na pripovjedanika“, te naglašava dinamičnost te komunikacije ,zbog postojanja dvaju parova pripovjedača i pripovjedanika“"(386).

U završnome dijelu autorica je još jednom potvrdila polaznu tezu o međusobnoj suradnji više pripovjedača u iznošenju jedne priče, istaknula njihovo ispreplitanje i izmjenjivanje i naglasila da se oni u slikovnici nikada potpuno ne stapaju već samo približavaju. Narančić Kovač svoju knjigu završava citatom iz jednoga od najvažnijih djela dječje književnosti, Alice u Zemlji Čudesa Lewisa Carrolla: „,...koja je korist knjige,' pomislila je Alica, 'bez slika i razgovora?"“(1865/2007: 1-2), čime ističe da slikovnice imaju velik značaj i posebno mjesto u književnosti. 
Smiljana Narančić Kovač knjigom Jedna priča - dva pripovjedača približava čitateljstvu teoriju slikovnice opisujući ju na detaljan način i potkrepljujući je primjerima. Budući da se slikovnica sve više prepoznaje kao zasebna umjetnost, ovo je istraživanje od iznimne važnosti za razvoj teorije o slikovnicama. Vrlo ju lako mogu razumjeti svi čitatelji - i oni koji se već bave teorijom slikovnice i oni koji ju tek počinju proučavati - stoga je izvrstan odabir za sve poklonike te složene likovno-književne forme.

Dorja Anić

\section{Blistav um i dobro srce}

Ivana Brlić-Mažuranić. 2016. Moji zapisci: dnevnici, memoari, molitve, putni $i$ drugi zapisi. Sabrana djela Ivane Brlić-Mažuranić: ostavština. Sv. 1 (6). Priredio Mato Artuković. Uredio Vinko Brešić. Slavonski Brod: Ogranak Matice hrvatske Slavonski Brod. 494 str. ISBN 978-953-6842-19-3, ISBN 978-953-6842-39-1

DOI: $10.21066 /$ carcl.libri.2017-06(01).0013

Šesti svezak u nizu Sabranih djela Ivane Brlić-Mažuranić urednika Vinka Brešića pod naslovom Moji zapisci donosi sveobuhvatan uvid u spisateljičinu rukopisnu ostavštinu koja je do sada bila manje poznata ili nepoznata čitateljima i istraživačima dječje književnosti. Uz prethodno objavljenih pet svezaka (Svezak 1: Pjesme i priče, Svezak 2: Romani, Svezak 3: Bajke i basne, Svezak 4: Članci (1903. - 1938.) i Svezak 5: Bibliografija), život i djelo spisateljice Ivane Brlić-Mažuranić cjelovito su prikazani besprijekornom znanstvenom objektivnošću i s mnogo brižnosti i odgovornosti prema dragocjenoj ostavštini Ivane BrlićMažuranić.

Svezak je priredio Mato Artuković. Sastoji se od dnevničkih zapisa, memoara, molitvi, putnih i drugih zapisa podijeljenih u šest dijelova po kronološkome kriteriju i po kriteriju vrste zapisa. Građa je poduprta nužnim historiografskim referencijama te biranim ilustrativno-dokumentarnim materijalom. Na kraju građe izrađen je vrlo vrijedan rječnik manje poznatih riječi i izraza te su uključena dva kazala: kazalo osobnih imena i kazalo toponima. Svi ti dodatci objašnjavaju pojedine zapise i čine građu jednostavnijom za razumijevanje u spisateljičinome osobnome kontekstu, ali i društveno-povijesnome kontekstu, te time čine cijelu knjigu pristupačnijom i zanimljivom ne samo u znanstvenome smislu, već i šire.

U prvome dijelu knjige preneseni su spisateljičini prvi zapisci, uključujući knjižicu putopisa i pjesama koja je najraniji zapis Ivane Brlić-Mažuranić. Spisateljica bilježi pjesme, prijevode i zabilješke od svoje jedanaeste godine života, kada počinju njezini dnevnički zapisi i putne bilješke s putovanja u Ogulin i putovanja iz Zagreba, preko Slovenije i Rijeke u Novi (13. travnja 1889. - 15. travnja 1889.). Slijede spisateljičine molitve, ispovijedi i vjerska promišljanja. Većina molitvi zapisana je 1891. godine, a dvije su napisane na Uskrs, jedna 1895., a druga 1896. godine. Zabilježen je i nedatirani ulomak zapamćenja iz djetinjstva, koji je vjerojatno nastao prije 1916. godine.

Drugi dio knjige čine dnevnički zapisi iz nekoliko vremenskih perioda: 1888. 1889., 1889. - 1891., 1911., 1913. i 1918. Spisateljičini dnevnički zapisi isprepliću se s raznim literarnim sadržajima, od kojih su neki zapisani na francuskome, njemačkome ili 